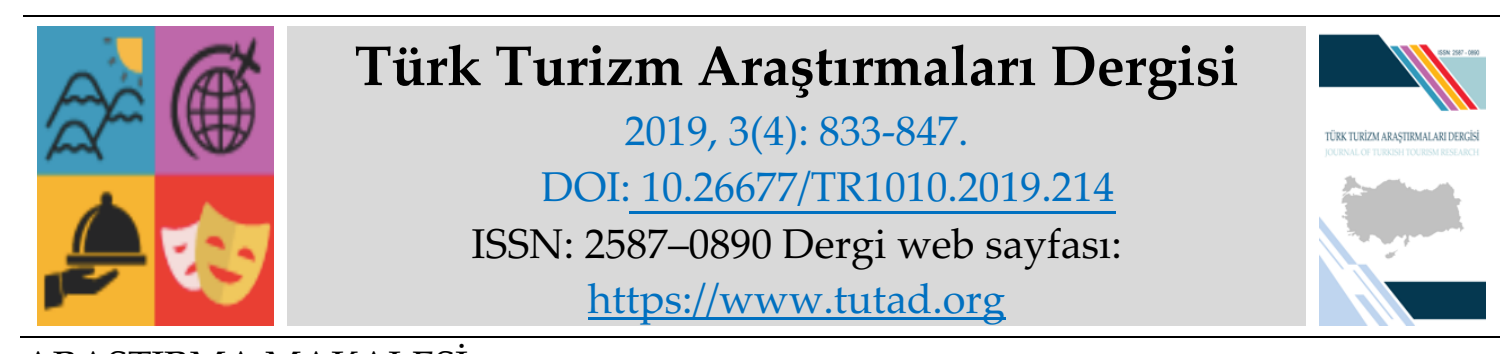

ARAŞTIRMA MAKALESI

\title{
Kültürel Mirasın Korunması ve Sürdürülmesinde Turist Rehberlerinin Rolü
}

Dr. Öğr. Üyesi Sıla KARACAOĞLU, Bilecik Şeyh Edebali Üniversitesi, Uygulamalı Bilimler Fakültesi, Bilecik, e-posta: sila.karacaoglu@bilecik.edu.tr

ORCID: https://orcid.org/0000-0001-7724-2188

Prof. Dr. Medet YOLAL, Anadolu Üniversitesi, Turizm Fakültesi, Eskişehir, e-posta: myolal@anadolu.edu.tr

ORCID: https://orcid.org/0000-0002-9834-2425

Öz

Kültürel mirasın korunması, yaşatılması ve aktarılmasında rol sahibi olan aktörlerden biri turist rehberleridir. Buradan hareketle, çalışma Kapadokya Bölgesi'nde hizmet veren turist rehberlerinin bölgedeki kültürel mirasın korunmasındaki ve aktarılmasındaki rollerini araştırmayı amaçlamaktadır. Yüz yüze görüşme tekniği ve e-posta aracılığıyla 17 profesyonel turist rehberiyle 29.12.2017-05.02.2018 tarihlerinde yarı-yapılandırılmış görüşme formu kullanılarak veri toplanmıştır. Elde edilen veriler betimsel analize tabi tutulmuştur. Araştırma sonucunda; turist rehberlerini turizmin diğer aktörleriyle karşılaştırdıklarında, Kapadokya'nın kültürel değerlerinin tanıtımı, korunması, sürdürülmesi ile kültürlerarası etkileşimin sağlanması konularında en fazla kendilerinin etkili olduğu sonucuna ulaşılmıştır. Ayrıca, turist rehberlerinin tur esnasında gördükleri yanlışları, eksiklikleri, tahribatları yerel yönetimler ve meslek odaları ile paylaşmasının önemine vurgu yapılmıştır. Elde edilen sonuçlar ışığında turist rehberlerinin bölgedeki kültürel mirasın korunmasındaki ve aktarılmasındaki rollerine ilişkin öneriler geliştirilmiştir.

* Bu çalışma 29-30 Nisan 2019 tarihleri arasında gerçekleştirilen 2. Turizm Rehberliği Kongresi'nde bildiri olarak sunulmuştur.

Anahtar Kelimeler: Turist Rehberi, Kültürel Miras, Koruma, Sürdürme, Kapadokya.

Makale Gönderme Tarihi: 01.07.2019

Makale Kabul Tarihi: 05.10.2019

Önerilen Atıf:

Karacaoğlu, S. ve Yolal, M. (2019). Kültürel Mirasın Korunması ve Sürdürülmesinde Turist Rehberlerinin Rolü, Türk Turizm Araştırmaları Dergisi, 3(4): 833-847.

(C) 2019 Türk Turizm Araştırmaları Dergisi. 


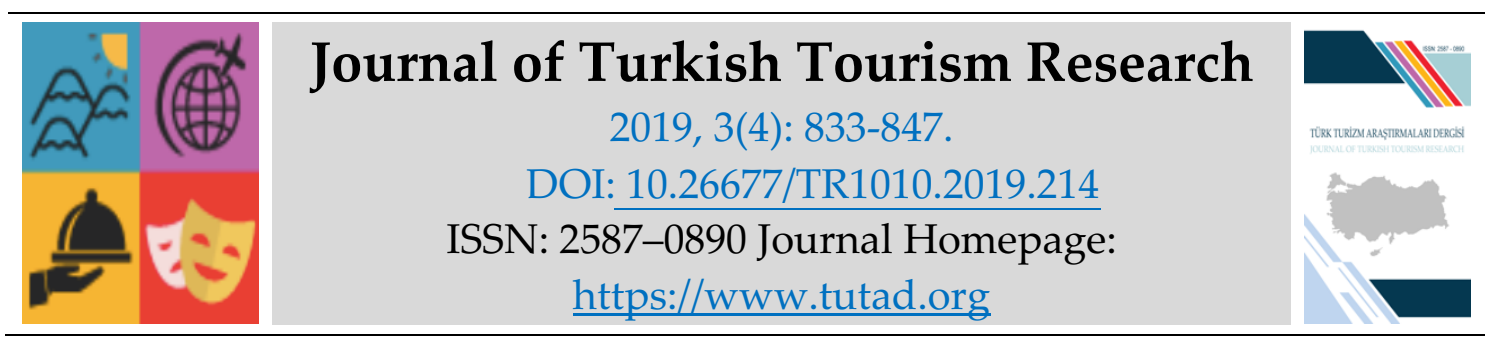

RESEARCH PAPER

\title{
Tour Guides' Role in Conservation and Sustainability of Cultural Heritage
}

Assistant Prof. Dr. Sıla KARACAOĞLU, Bilecik Şeyh Edebali University, Faculty of Applied Sciences, Bilecik, e-mail: sila.karacaoglu@bilecik.edu.tr

ORCID: https://orcid.org/0000-0001-7724-2188

Prof. Dr. Medet YOLAL, Anadolu University, Faculty of Tourism, Eskişehir, e-mail: myolal@anadolu.edu.tr

ORCID: https://orcid.org/0000-0002-9834-2425

\begin{abstract}
Professional tour guides play a significant role in protecting, sustaining and enabling cultural tourism to achieve its goals. As such, they act as the guards of the culture in line with the responsibility of their profession. Therefore, this study aims to examine the roles of tourist guides in protecting and transferring cultural heritage of Cappadocia, Turkey to the next generations. The study employed qualitative approach and used face-to-face and online interview forms to collect data from tour guides in Cappadocia. A total of 17 interviews were conducted from 29.12.2017 to 05.02.2018. Data were descriptively analyzed on the computer. Study results suggest that tour guides believe that they have higher liability for the protection, sustainability and promotion of the cultural assets in Cappadocia compared to other actors. Moreover, they claim that they are important agents in achieving intercultural interaction, and underline the importance of informing local governments and related bodies about the problems, defects and destruction. The paper ends with a discussion of the findings and a conclusion.
\end{abstract}

Keywords: Tour Guides, Cultural Heritage, Preservation, Sustainability, Cappadocia.

Received: 01.07.2019

Accepted: 05.10.2019

\section{Suggested Citation:}

Karacaoğlu, S. and Yolal, M. (2019). Tour Guides' Role in Conservation and Sustainability of Cultural Heritage, Journal of Turkish Tourism Research, 3(4): 833-847.

C 2019 Türk Turizm Araştırmaları Dergisi. 


\section{Gíriş}

Turizm, bir dizi ilişkili bileşenden oluşan açık bir sistemdir (Leiper, 1990; Gunn, 1994; McKercher, 1999). Temel olarak, turizm sisteminin arz, talep ve aracılar/bağlantılar olmak üzere üç bölümden oluştuğu söylenebilir (Hudman ve Hawkins, 1989; Burns ve Holden, 1995). Söz konusu sistemde turist rehberleri çok özel bir yere sahiptir. Bir aracı olarak turist rehberleri, sistemdeki arz unsurunun önemli birer parçasıdır. Turist rehberleri, turizm endüstrisinin bütün sektörlerinde ve endüstriyi ilgilendiren her alanda (tur operatörleri, seyahat acentaları, hükümetler, kamu kuruluşları, özel şirketler veya kendileri bağımsız olarak vb.) tüm paydaşlar için çalışabilirler (Pond, 1993). Bu niteliklerinden dolayı turist rehberleri genellikle ziyaretçiler için önemli bir hizmet sağlayıcı olarak kabul edilirler.

Turizm günümüzde, yaşamda anlam arama ve dünyayı anlamlandırma görevi üstlenmektedir. Buradan hareketle, turist rehberliğinin de tanımı ve içeriği değişmiştir. Dünya Turist Rehberleri Birliği Federasyonu (World Federation of Tourist Guide Associations) turist rehberini; "ziyaretçilere kendi tercih ettikleri dilde rehberlik eden ve genelde yetkili otorite tarafından verilmiş ve/veya onaylanmış alan yeterliliğine sahip olduğu bir bölgenin doğal ve kültürel mirasını anlatan kişi" olarak tanımlamaktadır (www.wftga.org). Pond (1993) turist rehberlerini "turistlerin gezmeye geldikleri yerleri anlamalarını sağlayan kişi" olarak ifade etmektedir. Bu bağlamda başarılı bir turist rehberi; turistleri mutlu eden, gezilen yerlerle ilgili olarak olumlu izlenim edinmelerini sağlayan, turistlerin beklentilerini karşılayacak doğru ve yararlı hizmetleri sunan ve gelecekteki turlara katılma isteklerini artıran nitelikte olmalıdır (Ap ve Wong, 2001).

Değişen dünya ve tüketici eğilimleri doğrultusunda, turist rehberlerinin turizm endüstrindeki işlevleri ve rolleri de her geçen gün değişmektedir. Bu doğrultuda turist rehberleri de çağdaş turizm anlayışında en önemli oyunculardan biri haline gelmektedir (Ap ve Wong, 2001; Hu, 2007). Dolayısıyla turist rehberleri, turizmin ve turistin ihtiyaçlarına karşılık verebilmeleri için yeni yaklaşımlara, iletişim becerilerine ve işbirliğine ihtiyaç duymaktadır (Aslantürk, 2003). Turist rehberleri aynı zamanda grup dinamiği, motivasyon, kültürel/etnik köken gibi konularda hakimiyet sağlamalarını sağlayan sosyolojik ve psikolojik alanlarda da eğitilmiş olmalıdırlar (Cohen vd., 2002). Bir diğer ifadeyle, turist rehberliği mesleği yeterli bilgi birikimi ve eğitimin yanı sıra oldukça çeşitli becerilere sahip olmayı da gerektirmektedir. Söz konusu özeliklerin bazıları kişisel olmakla birlikte bir diğer kısmı da mesleki rolleri kapsamaktadır (Çokal, 2015).

Turist rehberlerinin rolleri destinasyonlara göre değişiklik gösterebilmekle birlikte, literatürde bazı ortak roller ortaya konulmaktadır (Látková vd., 2017). Turist rehberinin en temel görevlerinden biri, ziyaret edilen destinasyon hakkında turistlere doğru ve eksiksiz biçimde bilgi vermesi ve bölgeyi tanitmasıdır (Rabotić, 2011). Bir diğer ifadeyle turiste yabancı bir destinasyonda ihtiyacı olan bütün bilgiyi sağlayan kaynaktır. Bunun yanı sıra, turist rehberleri sadece yol bulan bir kılavuz değildir; aynı zamanda turistlerin gördüklerinde anlam bulmalarına yardımcı olan manevi birer yol göstericidir (Cohen vd., 2002). Turist için yabancı bir yer olan destinasyon ile turist arasında bir bağ görevini yerine getirirken aynı zamanda bir halkla ilişkiler uzmanı, yol gösterici, eğlendirici ve danışman rollerini de oynamaktadır. Bütün bu rolleri bağlamında turist rehberlerinin acil durumlarla baş edebilmesi, turistlerin fiziki ve psikolojik ihtiyaçlarıyla ilgilenmesi, tur organizasyonundan kaynaklanan sorunları ve çatışmaları çözmesi, turistlerin şikâyetlerini ciddiye alması, onları rahatlatması, beklenmedik koşulları, krizleri yönetmesi gerekmektedir (Luoh ve Tsaur, 2014).

Turist rehberleri turistik deneyimi yönetme ve destinasyon imajın güçlendirme potansiyeline sahip, müşteriyle bire bir temas halinde olan çalışanlardır (Rabotić, 2010). Turist deneyimlerinde resmi aracilar olarak kabul edildiklerinden ev sahibi rolünü de üstlenmektedirler (Cohen, 1985; Smith, 1989; Jennings ve Weiler, 2006). Özellikle kültürlerarası ortamlarda, bir tercüman olarak 
hareket etmelerinin yanı sıra kültürü tanıtan, aktaran gönüllü bir temsilci olarak hareket etmeleri de gerekmektedir (Nozawa, 1992; McDonnell, 2001). Turist rehberleri, bir destinasyonun yaşayan kültürünü, yerel kültürel mirasını ve kültürel kimliğini misafirlere gösterip yorumlamaktadır. Bunu yaparken de tıpkı bir büyükelçi gibi hem tanıttığı kültüre hem de misafirlerin kültürüne saygı göstermektedir (Rabotić, 2011).

Turist rehberlerinin turizm endüstrisindeki önemine rağmen turist rehberleri üzerine yapılmış çalışmaların kısıtlı olduğu gözlemlenmektedir. Bu bağlamda turist rehberlerinin duygusal emek ve tükenmişlik ilişkisi (Kaya ve Özhan, 2012), hizmet içi eğitim seminerlerinin pazarlamadaki rolü (Korkmaz vd., 2011), iş yaşamındaki rolleri (Köroğlu, 2013), kişilik özellikleri ve meslek seçimi ilişkisi (Köroğlu, 2014), rehberlerin performanslarının değerlendirilmesi (Olcay vd., 2015) ve mesleki bağlılık ve ekonomik kaygıları (Yetgin ve Benligiray, 2019) gibi konular ele alınmıştır. Avcıkurt (2009) turist rehberlerinin çalışma alanlarındaki önemli bir işlevinin de kaynakların uzun vadeli kullanılması ve sürdürülebilir turizm anlayışının benimsenmesinde oynadıkları role dikkat çekmektedir. Bu durum özellikle kırılgan ve hassas bir yapıya sahip kültürel miras unsurlarının gezilmesi sırasında daha da önemli bir hâl alır. Bu saptamaya karşın turist rehberlerinin kültürel mirasın korunmasındaki işlevine ilişkin çalışmaların sayısının çok az olduğu görülmektedir. Dolayısıyla bu çalışmada turist rehberlerinin kültürel mirası nasıl algıladıkları ve Kapadokya' daki kültürel mirasın korunmasındaki ve aktarılmasındaki rollerini araştırmayı amaçlanmıştır. Elde edilen sonuçlar turist rehberlerinin bölgedeki kültürel mirasın korunmasındaki ve aktarılmasındaki rollerine ilişkin önerilerin geliştirilmesi açısından önemlidir.

\section{KAVRAMSAL ÇERÇEVE}

Kültür sözcüğü; uygarlık, üretim, eğitim ve sanatsal yanıyla farklı anlamlarda kullanılan geniş bir kavram olup çok çeşitli tanımlara sahiptir (Doğaner, 2013). Genel olarak kültür; geçmişten günümüze insanlığın sahip olduğu somut ve somut olmayan varlıkların bütününü oluşturan, toplumsal olarak öğrenilen, yeni nesillere aktarılan unsurların bütünü olarak ifade edilebilir (Boniface ve Fowler, 1993). Bozkurt'a (2016) göre kültür; toplumun sahip olduğu maddi ve manevi değerleriyle tarih, felsefe, ahlâk, bilim, sanat, teknik, spor, ekonomi, sanayi, eğitim, hukuk, sağlık, turizm vb. alanlardaki varlıkların ve bu varlıklara bağlı gelişmelerin oluşturduğu bir bütündür. Doğal çevrenin farklılığı kültüre yansırken, kültür de gerek doğal çevreyi gerekse toplumun yapısını etkilemektedir. Değişik kültürlerin ortaya çıkmasıyla insanların merak ve tanıma isteği artmış, bu durum eğlenme, dinlenme talebiyle birleşerek turizmin gelişmesine, coğrafya, kültür ve turizm arasındaki ilişkinin güçlenmesine neden olmuştur (Emekli, 2006). Söz konusu nedenle kültür, günümüzde turizm talebini oluşturan başlıca çekici unsurlardan biri haline gelmiştir.

Kültürel turizmin çok önemli bir alt dalını oluşturan kültürel miras turizmi gerek kentleri gerekse kırsal destinasyonları kalkındıran turizmin ana lokomotiflerinden biridir (Sigala ve Leslie, 2005). Yeni bir niş pazar olarak kabul edilen bu turizm türü, günümüzde pek çok ülkenin güncel turizm stratejisinin temel dayanağını oluşturmakta, yerel kültürü yükseltmek için kullanılmakta, turizmin mevsimsel ve coğrafi yayılımına yardımcı olabilmektedir (Richards, 1996; Timothy ve Nyaupane, 2009; Jansen-Verbeke ve McKercher, 2010). Birleşmiş Milletler Dünya Turizm Örgütü'nün (United Nations World Tourism Organisation-UNWTO) 2015 yılında yürüttüğü Turizm ve Kültür Araştırması'nın sonuçlarına göre uluslararası turizm hareketlerinin \%40'ının kültür turistleri tarafından gerçekleştirildiği görülmektedir (http://www2.unwto.org). Aynı araştırmaya göre kültür turizmi kapsamındaki seyahatlerin her geçen sene hızla artacağ anlaşılmaktadır. 
Kültürel miras; tarih, sanat veya bilim açısından olağanüstü evrensel değeri olan anıtlar, binalar ve arkeolojik sitlerin bütünü olarak tanımlanabilir (Huh, 2002). Kültürel miras turizmi ise evrensel değeri olan doğal ve insan yapısı bu çekiciliklerin ziyaret edilmesini içeren bir kavramdır. Kültürel miras turizmi ile ilgili unsurlar, birçok araştırmacı tarafından farklı şekillerde ele alınmıştır (Prentice, 1993; Smith 2006). Timothy ve Boyd (2006) kültürel mirası doğal (ekolojik), kültürel (antropolojik ve tarihi) veya endüstriyel (madencilik ve üretim) miras olarak kategorilere ayırmaktadır. Bu doğrultuda doğal tarih ve bilimsel unsurlar, tarımsal ve endüstriyel unsurlar, ulaşım unsurları, sosyo-kültürel unsurlar, insan eliyle inşa edilmiş unsurlar, askeri unsurlar, manzaralar, artistik unsurlar ve tarihi kişi ve olaylarla ilgili çekicilikler olmak üzere farklı boyutlarda ele alınabilmektedir.

Araştırmalar kültürel miras alanlarının insanlar tarafından bilginin geliştirilmesi, merakın giderilmesi, nostalji duygusunun tatmin edilmesi, ruhsal olarak iyileşme, rahatlama, evden uzaklaşma gibi nedenlerle ziyaret edildiğini göstermektedir (Timothy ve Nyaupane, 2009). Kültürel miras turizmi; kültürel mirasa ve ekonomiye büyük ölçüde katkıda bulunması ile birlikte, kültürel mirasın korunmasına, ulusal kimliğin oluşturulmasına ve güçlendirilmesine yardımcı olmaktadır (Ariffin ve Maghzi, 2012). Ancak pek çok çalışmada da belirtildiği üzere bir destinasyonda turizmin gelişimi kültürel miras çekicilikleri üzerinde olumsuz etkiler yaratmaktadır (Fyall ve Garrod 1998; Tosun, 2001; Timothy ve Boyd 2006). Bu olumsuz etkilerin temel nedenlerinden biri aşırı ve özensiz kullanımdır. Pek çok kültürel miras unsuru özellikle belirli dönemlerde bir ziyaretçi yoğunluğu yaşamaktadır. Bu yoğunluk ve özellikle ziyaretçiler arasındaki kimi kişilerin özensiz tutumları, karşılaşılan önemli sorunlar arasında yer almaktadır.

Kültürel miras alanlarıyla ilgili bir diğer sorun çöp kaynaklı çevre kirliliğidir. Gerek çöp atılabilecek alanların yetersizliği gerekse özellikle ziyaretçilerin bu konudaki özensizliği kültürel miras alanlarında çevre kirliliği sorununa yol açmakta, bu durum kültürel miras alanına zarar vermenin yanında ziyaretçiler arasında memnuniyetsizliğe neden olmaktadır (Timothy ve Nyaupane, 2009). Ziyaretçilerin anı bırakmak veya yanlarında anı olarak götürmek üzere kültürel miras alanlarında olumsuz sonuçlar doğuran eylemler içinde olduğu da gözlemlenmektedir. Bunun en bariz örneklerinden biri de Kapadokya'daki kaya kiliselerinde görülmektedir. Özellikle mağaraların iç kısımlarına isimlerin kazınması ve hatta bunun sprey boya ile yapılması gibi uygunsuz davranışlar bu kültürel miras unsurları üzerinde geri döndürülemez etkiler bırakmaktadır. Bu nedenle kültürel mirasın korunması ve gelecek kuşaklara aktarılması gerekliliği ortaya çıkmaktadır.

Kültürel mirasa dayalı turizm hareketlerinin yoğunlaştığı bölgelerde yüksek düzeyde bilgiye sahip turist rehberliği hizmeti talep edilmektedir (Köroğlu, 2013). Bunun nedeni olarak turist rehberlerinin bir destinasyonun ilgi çekici yerleri ve kültürü hakkında bilgi sahibi olmaları ve hizmet ve iletişim becerileri sayesinde turistlerin seyahatlerini tur olmaktan çıkarıp bir deneyime dönüştürme yetisine sahip olmaları gösterilmektedir (Ap ve Wong, 2001). Bunun yanında, turist rehberlerinin tur kapsamında pek çok işlevi yerine getirdikleri bilinmektedir. Örneğin Yamada'nın (2011) Japonya'da yaptığ1 çalışmada turist rehberlerinin çevresel rolleri ve uygulamalarına dikkat çekilmektedir. Araştırma sonuçlarına göre Japonya'da turist rehberleri özellikle eko turizm politikalarının uygulanmasında bir aracı olarak görülmektedir. Buradan hareketle yazar, turist rehberliği mesleğini koruma ve çevresel eğitimin kolaylaştırıcısı olarak görmektedir. Turist rehberlerinin tur katılımcılarının ziyaret edilen topluluk, kültür ve çevreye ilişkin anlayış ve saygı tutumlarının geliştirilmesinde önemli bir işleve sahip olduğu ifade edilmektedir (Weiler ve Black, 2015). Söz konusu işleve bağlı olarak turist rehberleri yorumlayıcı rehberlik, mesajların aktarılması, örnek davranış sergilenmesi, katılımcıların istenen yönde davranış sergilemesi için yönlendirilmesi ve ikna edici iletişim stratejilerini kullanabilmektedir. Bu stratejiler kırılgan ve hassas bir yapıya sahip destinasyonların gezdirilmesi esnasında daha da 
önemli bir duruma gelmektedir. Bu öneme dikkat çeken Van der Merwe (2016) kültürel miras unsurlarına ilişkin kararların alınmasında ve politikaların geliştirilmesinde turist rehberlerinin önemli birer paydaş olduklarını vurgulamaktadır. Kültürel miras turizminin korunmasında ve sürdürülmesinde kritik rol üstlenen, bilgi aktarırken, açıklama yaparken ve hikâyeler geliştirirken kültürel miras unsurlarından yararlanan, turistler için unutulmaz deneyimler hazırlayan turist rehberlerinin (Köroğlu, 2013) kültürel miras algılarının bilinmesi ve kültürel mirasın korunmasında kendilerine biçtiklerin rolün ortaya konulması önemlidir. Dolayısıyla, bu çalışma ile kültürel mirasın tanıtımında aracı olan turist rehberlerinin algılarını tespit ederek literatüre katkı sağlanması beklenmektedir.

\section{YÖNTEM}

Araştırmada, Kapadokya destinasyonunda çalışan turist rehberlerinin bölgedeki tarihi ve kültürel değerlerin korunmasında ve bu değerlerin gelecek nesillere aktarılmasında nasıl rol oynadığının tespit edilmesi amaçlanmıştır. Söz konusu amaç doğrultusunda, literatürden yararlanarak iki adet açık uçlu görüşme sorusu hazırlanmıştır. Telefon görüşmesi ve e-posta aracılığıyla yarı-yapılandırılmış görüşme formu kullanılarak 17 turist rehberinden 29.12.201705.02.2018 tarihlerinde kartopu örnekleme yöntemiyle veri toplanmıştır. Kartopu örnekleme bir çalışmada belirli niteliklere ya da gerekli özelliklere sahip denekleri bulmak için en iyi yoldur (Yolal, 2016). Bu örnekleme yönteminde süreç inceleme kıstaslarına uygun bir deneğin seçilmesiyle başlamaktadır. Temas kurulan ilk kişiden veri toplandıktan sonra o kişinin yardımıyla bir başkasıyla, daha sonra yine aynı yolla bir başkasıyla temas kurulmakta, kartopu etkisi şeklinde, zincirleme olarak örnek büyütülmektedir. Bu araştırmada da Kapadokya bölgesinde uzun yıllardır çalışmakta olan bir turist rehberi ile ilk temas gerçekleştirilmiş, kendisiyle görüşüldükten sonra görüşülebilecek katılımcı önerileri istenmiştir. İzleyen veri toplama sürecinde de bu yöntem kullanılmıştır. Bu görüşmelerde aşağıdaki araştırma sorularının yanıtları aranmıştır:

1) Kapadokya Bölgesi'ndeki turist rehberlerinin bölgedeki tarihi ve kültürel değerlerin korunmasındaki rolleri sizce nelerdir?

2) Kapadokya Bölgesi'ndeki turist rehberlerinin bölgedeki tarihi ve kültürel değerlerin gelecek nesillere aktarılmasındaki rolleri sizce nelerdir?

Nitel veri, ham verinin çalışma konusu olan olgunun ussal bir tanımı ve açılamasının yapılabilmesi için belirli analitik süreçler kullanılarak analizi veri setinin bütüncül bir şekilde yorumlanmasıdır (Altınay vd., 2016). Nitel bir yöntemin benimsendiği bu çalışmada elde edilen veriler araştırmacılar tarafından bilgisayar ortamına aktarılmış, düzenlenmiş ve betimsel analize tabi tutulmuştur. Betimsel analiz, bireylerin görüşlerini belirgin bir biçimde ortaya koymak üzere veri setinin önceden tanımlanmış temalar temelinde özetlenmesi ve yorumlanmasıdır. Betimsel analizde, farklı katılımcıların aynı soru hakkındaki farklı düşüncelerinden elde edilen görüşlerin aktarılması söz konusudur. Bu yöntem, karmaşık ve zor olmakla birlikte ulaşılması oldukça zor verilerin elde edilmesine yardımcı olmaktadır (Yıldırım ve Şimşek, 2005). Katılımcılara K1, K2, K3...K17 şeklinde kodlar verilmiş ve katılımcılar çalışmada bu şekilde sunulmuştur. 


\section{BULGULAR}

\section{Turist Rehberlerinin Sosyo-Demografik ve Sosyo-Ekonomik Durumları}

Turist rehberlerinin cinsiyetleri incelendiğinde katılımcılardan 12'sinin erkek, 5'inin kadın; çoğunluğun ise bekâr olduğu (11 kişi) görülmektedir. Yaş ortalamalarının ve dağılımlarının $(\% 31,7)$ birbirine oldukça yakın olduğu anlaşılmaktadır. Turist rehberlerinin eğitim durumlarına göre lisans (12 kişi), ön lisans (3 kişi) ve yüksek lisans (2 kişi) mezunu oldukları; mesleki açıdan 14 kişinin aktif olarak turist rehberliği hizmeti gerçekleştirdiği saptanmıştır. Söz konusu turist rehberlerinin çalışma sürelerinin beş yıl ve üzeri olduğu ve yarısından fazlasının (13 kişi) bağımsız olarak çalıştığı belirlenmiştir. Araştırmaya katılanların ruhsatname ve çalışma kartına ilişkin bilgiler incelendiğinde ise 14'ünün ülkesel, üçünün ise bölgesel turist rehberi olduğu, iki turist rehberinin Kültür ve Turizm Bakanlığının gözetimi ve denetimi altında birlikler tarafından düzenlenen sertifika programı aracılığıyla ruhsatnamelerini aldığı sonucuna ulaşılmıştır.

Turist rehberlerinin çalışma kartlarının tamamında İngilizce dilinde hizmet verdiği; ikinci dil olarak ise Almanca (3 kişi), Japonca (2 kişi) ve İtalyanca (1 kişi) dillerinde hizmet verdiği anlaşılmaktadır. Hizmet verilen milliyetler sırasıyla; Amerikalı (12 kişi), Türk (10 kişi), Alman (8 kişi), Avusturyalı (8 kişi), İsviçreli (7 kişi), Japon (6 kişi), Koreli (5 kişi), Çinli (4 kişi), Hintli (4 kişi), İtalyan (3 kişi) ve Kanadalı (3 kişi) turistlerdir. Son olarak katılımcılara, turist rehberliği dışında ikinci bir işle uğraşıp uğraşmadıkları sorusu yöneltilmiştir. Üç kişinin farklı bir iş yaptığ (üniversitede sözleşmeli öğretim görevliliği, yolcu taşımacılığı, otomobil alım-satımı ile tarım ve hayvancllık), 14 kişinin ise tek gelir kaynağının turist rehberliği mesleği olduğu bulgusuna erişilmiştir.

\section{Turist Rehberlerinin Doğal ve Kültürel Mirasın Aktarılmasındaki ve Korunmasındaki Rolleri Hakkındaki Görüşleri}

Araştırmaya katkı sağlayan turist rehberlerinden öncelikle "Kapadokya Bölgesi'ndeki turist rehberlerinin bölgedeki tarihi ve kültürel değerlerin korunmasındaki rolleri sizce nelerdir?" sorusuna yanıt vermeleri istenmiştir. Turist rehberleri, turistle yüz yüze ve yoğun iletişimde olmaları nedeniyle turizm endüstrisinin diğer sektörlerindeki çalışanlardan farklı bir yere ve role sahip olduklarına işaret ederek, bölgedeki doğal ve kültürel mirasın çıkarlarını koruyan en önemli paydaş olduklarını vurgulamışlardır.
“Kapadokya'daki doğal ve kültürel mirasın korunmasına en çok turist rehberleri hassasiyet göstermelidir. Turistlerin, ziyaret edilen yerlerde sorumlu davranışlar sergilemelerini sağlamalıdır. Bölgede hizmet veren turist rehberleri, Göreme Açık Hava Müzesi'ndeki kiliselerin duvar ve tavanlarında yer alan fresklerin astrlarca karanlık ortamda kalabildiği için günümüze kadar gelebildiğini, suni ışıtan zarar görüp tahrip olmaması için fotoğraf ve kamera kullanımının kesinlikle yasak olduğunu turistlere anlatarak onları kültürel mirasın korunması konusunda bilinçlendirmelidir" $(K, 9)$.

Çevresel yorumcu olarak turist rehberleri doğal çevreye duyarlı davranış sergilemeleri konusunda turistleri motive etmekte ve uzun dönemde çevreci davranışlarının gelişmesine katkı sağlamaktadır. Bu bakımdan, turist rehberleri bilgi aktarırken ve turistlerle bölge arasında bir etkileşim oluştururken verdikleri bilgiler konusunda dikkatli ve hassas olmalıdır (Howard vd., 2001). Bu konuya dikkat çeken bir turist rehberinin görüşleri şöyledir:

"Mağaralardaki ve kiliselerdeki freskler erken Hristiyanlık döneminden kalan ve günümüze kadar gelen çok değerli ve hassas kültürel miraslardır. Kaya boyamaları yapılmadan 15 gün önce din adamları oruç tutmuş, ardından boyaları kutsayarak freskleri resmetmiştir. Turist 
rehberlerinin fresklerin oluşturulmasındaki bu zorlu süreçler hakkında turistleri bilgilendirmesiyle ve yönlendirmesiyle fresklerin zarar görmesinin önlenmesine ve kültürel mirasın korunmasına, sürdürülebilirliğine yardımcı olmaları gerekmektedir" $(K, 3)$

Bir başka katılımcıya göre fresklerin korunmasına ilişkin turist rehberinin sorumlu rolüne ilişkin görüşleri ise şu şekildedir:

"Freskler; ışıktan, kalabalığın yarattı̆̆ı insan nefesinin yoğunluğundan zarar görebiliyor. Bu bakımdan turist rehberinin, ziyaretçi grubunu fresklere zarar verecek tüm konularda önceden bilgilendirmesi ve içeride kalma süresini aşmamaları konusunda uyarması gerekmektedir" $(K, 12)$.

Turistler; destinasyonun kültürünü, geleneklerini, somut ve somut olmayan değerlerini öğrenmek için turist rehberlerine ihtiyaç duymaktadırlar (Tosun ve Temizkan, 2004). Bu noktada, turist rehberleri, çevrenin korunması, sosyo-kültürel unsurların bozulmadan devam ettirilmesini sağlamaya yardımcı olmalıdır $(\mathrm{Hu}, 2007)$. Turist rehberinin tanıtım işlevine ilişkin olarak bir katılımcı şunları ifade etmiştir:

"Turist rehberleri, turun başlangıcindan sonuna kadar turistle birebir temas halindedir. Somut ve somut olmayan kültürel değerlerin tanıtımda anahtar rol oynamasının yanı sıra bu kaynakların tahribatına yönelik turistleri bilinçlendirmeli, eğitmeli ve uyarmalıdır" (K, 8).

Katılımcılar doğal ve kültürel mirasın tanıtılmasından, aktarılmasından ziyade ticari kaygıyla tur satışına odaklanan turist rehberlerinin kültüre ve ülke imajına verdikleri zarara dikkat çekmektedir. Bu konuya ilişkin olarak katılımcılardan birinin görüşleri şu şekildedir:

"Maalesef bölgedeki kaçak turist rehberi sorunu, yeni yasaya ve yaptırımlara rağmen aşılamamaktadır. Ticari kaygllardan dolayı pek çok turist rehberi taban ücretin altında çalışmayı kabul etmektedir. Yine bazı turist rehberlerinin maddi önceliklerden dolayı turlarında, Kapadokya'nın doğal, tarihi, kültürel mirasının aktarılmasına öncelik vermek yerine balon turu, hamam satışı, hediyelik eşya, çömlek ve halı satışı, kalitesiz öğlen yemeğ i gibi tamamıla satış üzerine kurulu turlar düzenlediğine şahit olmaktayız. Meslek odalarının bu duruma acil müdahale etmesi gerektiğini düşünüyorum" $(K, 15)$

Turist rehberleri kaynakların uzun vadeli kullanılmasında ve sürdürülebilirliğinde önemli rol oynamaktadır (Köroğlu vd., 2012). Buradan hareketle, turist rehberleri doğal ve kültürel mirasın korunması ve devamlılığı için tur esnasında gördükleri yanlışları, eksiklikleri, tahribatları ilgili kamu kurumlarına ve meslek odalarına bildirmenin önemine vurgu yapmaktadırlar:
“Özellikle plansız ve kanuna aykırı yapılaşmanın doğal güzellikler üzerindeki olumsuz etkisi son zamanlarda medyaya dahi taşınmış bir konudur. Geçmişten bu yana bölgede yapılan büyük otellerle ve yeni tip konut alanlarıyla bölgenin dokusu harap edilmiştir. Doğal, tarihi ve kültürel varlıklarm korunmasında turist rehberlerinin bölgede gördüğü eksiklikleri ve yanlış uygulamaları yerel yönetimler ve meslek odaları ile paylaşması ve daha sonra bu sorunların giderilip giderilmediğinin takibini yapması şartıı" $(K, 17)$.

Katılımclar meslek odası, yerel yönetimler ile Kültür ve Turizm Bakanlığı'nın işbirliğinde Kapadokya' daki kültürel mirasın korunması ve sürdürülmesi için sosyal sorumluluk projelerinin geliştirilmesinin, turist rehberlerinin de bu projelerde yer almasının gerekli olduğunun altını çizmişlerdir.

“Dünya Miras Alanı'na ait bir yönetim planı mevcut değildir. Bu alan içinde yer alan farklı büyüklüklerde ve niteliklerdeki ören yeri ve gezi rotalarıla ilgili olarak ayrn ayrn ziyaretçi yönetim planları hazırlanmalıdır. Dünya Miras Alanı'ndaki farklı alanlara ilişkin ziyaretçi 
yönetim planları hazırlanırken tur operatörlerinin ve rehberlerin görüşünün alınmasının, doğal ve kültürel mirasın korunması ile sürdürülmesinde birlikte projeler geliştirilmesinin şart olduğunu düşünüyorum" (K, 2).

Yukarıda ön plana çıkarılan katılımcı görüşlerinde de yer aldığı gibi turist rehberlerinin kendilerini turizm endüstrisinde lokomotif rol oynayan, doğal ve kültürel mirasın korunması ile sürdürülmesinde önemli görevler üstlenen ve bu açıdan en sorumlu paydaş olarak gördükleri anlaşılmaktadır. Bu bulguların Yamada'nın (2011) ve Van der Merwe'nin (2016) araştırma sonuçları ile uyumlu olduğu anlaşılmaktadır.

\section{Turist Rehberlerinin Tarihi ve Kültürel Değerlerin Gelecek Nesillere Aktarılmasındaki Rolleri}

Bir kültür elçisi rolü üstlenen turist rehberleri, yerel halk ile turistler arasında bağ kurarak kültürel aracilıkta bulunmaktadırlar. Turistlerin merak ettiği somut ve somut olmayan miras varlıkları, onlarda merak uyandıran unsurları yorumlayıp anlatarak söz konusu değerlerin gelecek nesillere aktarılmasına yardımcı olmaktadır (Yu vd., 2002). Turist rehberlerine yöneltilen "Kapadokya Bölgesi'ndeki turist rehberlerinin bölgedeki tarihi ve kültürel değerlerin gelecek nesillere aktarılmasındaki rolleri sizce nelerdir?" sorusuna verilen cevaplar incelendiğinde, bölgenin değerlerini turiste ve gelecek nesillere aktarımdaki en iyi ve kilit turizm paydaşının turist rehberlerinin kendileri olduğu konusunda hemfikir oldukları anlaşılmaktadır.

"Turlarda turistlerin pek çoğunun, bölgenin doğal oluşumları, tarihi, kültürel unsurları konularında yeterli ve doğru bilgiye sahip olmadığın görüyoruz. Bu noktada, turist rehberlerinin bölge hakkında gerçek ve güvenilir bilgi sağlayarak kültürel mirasın bir temsilcisi olarak onun en iyi şekilde aktarılmasına yardımo olan başlıca kişiler olduğu açıtıı" $(K, 6)$.

Bir bölge veya ülke kültürünün sürdürülebilirliğinin sağlanabilmesi, turist rehberlerinin kültür elçiliği rolünü doğru bir şekilde anlayıp uygulamasına bağlıdır. Diğer bir ifadeyle turist rehberleri, mesleklerinin gerektirdiği işlev ve niteliklere sahip olmalarının yanı sıra, ülkesi adına bir kültür elçisi olduğunun da bilincinde olmalıdır (Toker, 2011). Bu doğrultuda katılımcılardan biri kültür elçisi rolünün altını çizmiştir:

“Turist rehberleri, kültür elçisi sıfatıyla yabancı turistlere milli kültürümüzü aktaran, Türk toplumu ve bölge halkı hakkında turiste en doğru bilgiyi sunan aktörlerdir. Bu bakımdan turist rehberleri, kültürlerarası iletişim kurabilmek ve kültürel miras varliklarmı gelecek nesillere aktarabilmek için yeterli eğitim, bilgi ve donanıma sahip olmahıdır. Bu açıdan turist rehberlerinin hizmet verdikleri turizm türü ve turist profili özelinde uzmanlaşmasının büyük önem taşıdığın düşünüyorum" (K, 13).

Turist rehberinin, bölge ya da ülkenin dışarıya bakan penceresi olmaları ve ziyaret edilen yerlerin önemini vurgulamak gibi bir misyonu yerine getiriyor olmaları, onların hem kültür elçisi hem de halkla ilişkiler rollerinin olduğunu göstermektedir. Turist rehberlerinin görevinin karşılama ve bilgilendirmeden öte bir rol olup, doğal ve kültürel mirası eğlenceli bir şekilde turistlere yorumlayarak aktarması beklenmektedir (Şenol ve Aliyev, 2015). Bu açıdan turist rehberleri, kültürel değerleri ilham verici ve eğlendirici bir şekilde aktarmalıdır (Ap ve Wong, 2001). Buradan hareketle, katılımcllardan birinin görüşleri şu şekildedir:

"Turist rehberleri, ziyaret edilen bölgenin doğal, tarihi, arkeolojik ve kültürel değerlerini en doğru ve etkin şekilde anlatan, yorumlayan, aktaran kişilerdir. Turist rehberleri yüksek 
bilgiye sahip olmanın yanı sıra doğal ve kültürel mirası turistlere aktarırken iyi bir öğretmen ve hikâyeci olmalıdı" $(K, 1)$.

Turist rehberlerinin bir kültürü yorumlamaları, ziyaretçilerin deneyim zenginliğinin artırılmasında çok önemli bir rol oynamaktadır. Çünkü turist rehberlerinin bilgilerini, destinasyondaki çekicilikleri ve bölgenin kültürünü anlayıp bunları uygun iletişim teknikleriyle, turistlere aktarabilmeleri turu bir geziden çok bir deneyime dönüştürmektedir (Reisinger ve Steiner, 2006). Deneyim konusuna atıfta bulunan katılımcılardan birinin konuya ilişkin ifadeleri şu şekildedir:

"Turist rehberleri turistlerin destinasyonu ve kültürel değgerleri anlamasına, yaşamasına ve deneyim kazanmasına yardımcı olmaktadır. Bölgedeki çanak-çömlekçilik zanaatı, el işleri, yemek kültürü, folklor, müzeler, ören yerleri vb. tarihi ve kültürel unsurlar turist rehberleri sayesinde turiste tanitılmaktadır. Böylece turist rehberleri, söz konusu varlikların zaman içinde unutulmamasina ve sürdürülmesine katkıda bulunmaktadır" $(K, 10)$.

Araştırmaya katılan turist rehberlerinin görüşleri bir bütün olarak incelendiğinde, Kapadokya' daki tarihi ve kültürel değerlerin gelecek nesillere aktarılmasında kendilerinin kültür elçisi rolünü doğru algıladıkları aşikârdır. Yukarıda ifade edilen söylemlerinden de anlaşılacağı gibi daha iyi hizmet vermek için donanımlı ve konusunda uzmanlaşmış turist rehberlerinin hem bilgilendirici hem de eğlenceli bir şekilde turistlere doğal ve kültürel mirası aktarması beklenmektedir.

\section{TARTIŞMA, SONUÇ VE ÖNERILLER}

Günümüzde pek çok ülke doğal, tarihi ve kültürel potansiyeli zengin olan bölgeleri, kültür turizmi ve onun alt dalı olan kültürel miras turizmi çerçevesinde koruma ve sahip oldukları değerlerin sürdürülebilirliğini sağlama çabası içindedir. Bu bağlamda, turizm endüstrisinin paydaşlarından biri olan turist rehberlerine önemli görevler düşmektedir. Turist rehberleri, turistlerin destinasyona gelişinden ayrılışına kadar onlarla en fazla zaman geçiren, turistik değerlerin doğru ve güvenilir bir şekilde aktarılmasında, yorumlanmasında bir kültür elçisi gibi rol oynayan, kaliteli ve otantik deneyimler yaşanmasına aracı olan, doğal, tarihi ve kültürel miras unsurlarının yaşatılmasında, korunmasında, sürdürülmesinde, gelecek kuşaklara aktarılmasında sorumluluğu olan, yerel halk ve turistler arasında köprü kuran kişilerdir.

Araştırma bulguları, katılımcların doğal, tarihi ve kültürel mirası en iyi tanıtan, yansıtan, yorumlayan, aktaran, koruyan turizm paydaşının turist rehberleri olduğunu algıladıklarını göstermektedir. Söz konusu miras değerlerinin turistler tarafından kullanımında, turistlerin bu alanlar üzerindeki tahrip edici davranışları üzerinde turist rehberlerinin, kendilerini sorumlu hissettikleri sonucuna varılmıştır. Katılımcılar, gönüllü bir eğitici gibi kültürel miras kaynaklarının korunması konusunda turistleri bilgilendirmeleri ve bilinçlendirmeleri gerektiğini ifade etmişlerdir. Tur esnasında çevrede gördükleri yanlışları, eksiklikleri, tahribatları yerel yönetimler ve meslek odaları ile paylaşmanın önemine dikkat çekerek mevcut sorunların çözülüp çözülmediğinin takibinin yapılmasının da gerekliliğine işaret etmişlerdir. Bu doğrultuda, özellikle alan yönetimi ve ilgili yerel birimlerin turist rehberleri ile istişare ve işbirliği içerisinde çalışmaları bölgede yaşanan sorunların üstesinden gelinmesi açısından önemlidir. Bu işbirliği aynı zamanda yerel halkın beklentilerinin karşılanmasına da katkı sağlayacaktır.

Göreme Milli Parkı ve Kapadokya, Türkiye'deki Dünya Miras Alanları içinde en geniş alana sahip, içinde çok sayıda ve farklı idari statülerde yerleşim birimlerini barındıran bir turistik destinasyondur. Bu nedenle Dünya Miras Alanı için diğer alanlardan farklı olarak özel ve özerk bir yönetim modelinin oluşturulması zorunludur (UNESCO Türkiye Milli Komisyonu, 2009). 
Araştırma bulguları da bölgeye ait bir yönetim planının mevcut olmadığını göstermektedir. Bu eksiklikten hareketle, turist rehberleri ziyaretçi yönetim planları hazırlanırken tur operatörlerinin ve turist rehberlerinin görüşünün alınması ile taşıma kapasitesinin sağlanmasının faydalı olacağını ifade etmektedirler. Turist sayısının fazlalığı gerek kiliselerde fresklerin korunmasında gerekse peri bacalarında kontrolün sağlanamamasına ve tahribata yol açmaktadır. Ayrıca katılımcılar, meslek odaları, yerel yönetimler ile Kültür ve Turizm Bakanlığı işbirliğinde Kapadokya'daki doğal, tarihi ve kültürel mirasın korunması ve sürdürülmesi için sosyal sorumluluk projelerinin geliştirilmesinin, turist rehberlerinin de bu projelerde yer almasının gerekli olduğunu belirtmişlerdir.

Araştırmanın sonuçları turist rehberlerinin bölgedeki tarihi ve kültürel değerlerin gelecek nesillere aktarılmasında kendilerini bir kültür elçisi gibi algıladıklarını göstermektedir. Bu sonuçlar Weiler ve Black'in (2015) çerçevesini çizdiği turist rehberlerinin rolleriyle de uyumluluk göstermektedir. Turist rehberleri, tur süresince sadece bilgi vermekle değil, ülkelerinin kültürel değerlerine de her yönden katkı yapmakla yükümlüdürler. Diğer bir ifadeyle, turist rehberleri ülkenin kültürel değerlerini korumada, tanıtmada örnek kişilerdir. Kültürel mirasın gelecek nesillere aktarılması ise söz konusu değerlerin iyi bir şekilde korunmasıyla gerçekleşebilir (Çokal, 2015). Katılımcılar, turistlerle yerel kültür arasındaki bağı kurarak onlara en doğru ve güvenilir bilgileri aktarırken bunu eğlendirici bir anlatımla yorumlamalarının önemine vurgu yapmışlardır. Bunu gerçekleştirirken aracı rolü ile ev sahibi toplum ve ziyaretçiler arasındaki kültürel etkileşimi dengeli bir şekilde sağlamaları, empati yapabilmeleri, bazı sosyal ve kişilerarası iletişim becerilerine sahip olmaları ve uygun davranışlarıyla örnek olmaları gerekmektedir (Toker, 2011). Böylece, hem yerel halkın koruma bilincinin oluşmasına hem de turistlerin gittikleri destinasyonun doğal ve kültürel varlıklarının değerlerini anlamasına, korunmasına ve gelecek nesillere aktarılmasına yardımcı olması sağlanabilir (Rabotić, 2008).

Elde edilen sonuçlar ışığında turist rehberlerinin bölgedeki doğal, tarihi ve kültürel mirasın korunmasındaki ve aktarılmasındaki rollerine ilişkin öneriler geliştirilmiştir. Öncelikle, turist rehberlerinin en önemli rollerinden biri olan kültür elçiliğinin gerçekleşebilmesi için yeterli bilgi ve donanıma ihtiyaç duyulmaktadır. Bu bakımdan, turist rehberlerinin ilgili fakültelerden mezun olmaları ve hizmet içi eğitimlerle bilgi ve deneyimlerinin geliştirilmesi önem arz etmektedir. Bu doğrultuda, turizm rehberliği bölümlerinin müfredatında, doğal, tarihi ve kültürel mirasın korunmasında, sürdürülmesinde ve gelecek nesillere aktarılmasında turist rehberlerinin rollerine ilişkin kapsamlı derslere yer verilmesinin faydalı olacağı düşünülmektedir. Bunun yanı sıra Kültür ve Turizm Bakanlığı'nın zorunlu tuttuğu uygulama gezilerinin süresinin uzatılması ve daha kapsamlı hale getirilmesi yararlı olacaktır.

Kapadokya Bölgesi'ndeki alan yönetiminin ve ziyaretçi planlamasının uzman bir kadro ile yapılması gerekmektedir. Bu uzman grup oluşturulurken de mutlaka tur operatörleri ve turist rehberlerinden temsilciler bulunmalıdır. Bölgedeki doğal, tarihi ve kültürel mirasın sürdürülmesi için turistler bilgilendirilmeli, bilinçlendirilmeli ve bu değerlerin korunması için teşvik edilmelidir. Ormsby ve Mannle (2006) turist rehberlerinin destinasyonun korunması konusunda yerel halkı bilgilendirici rollerinin altını çizmektedir. Bu doğrultuda yerel halkın dünya miras alanı hakkında turist rehberleri aracılığıla bilgilendirilmesi ve bu alandaki varlıkların korunması ve gelecek nesillere aktarılmasında bilinçlendirilmesi gerekmektedir. Bu türden bir işbirliği Kapadokya'nın değerlerinin sürdürülebilir kılınmasına da önemli katkılar sağlayacaktır.

Bölgede çalışan kaçak turist rehberleri, gerek ülke imaj1 ve turizm gelişimini olumsuz etkileyeceğinden gerekse doğal ve kültürel mirasın korunması ile sürdürülmesinde olumsuz rol oynayacağından Kültür ve Turizm Bakanlığının denetimlerini artırması gerekmektedir. Kaçak rehberlere yönelik cezai yaptırımların ağırlaştırılması da caydırıcılık açısından önem 
taşımaktadır. Bu konunun önemine ilişkin olarak acentaların ve tur operatörlerinin bilinç düzeylerinin artırılmasına ilişkin önlemlerin alınması arzulanan sonuçların elde edilmesinde önem arz etmektedir.

Bu çalışmada, Kapadokya Bölgesi'nde hizmet veren turist rehberlerinin doğal, tarihi ve kültürel değerlerin korunmasında, yorumlanmasında, sürdürülmesinde ve gelecek nesillere aktarılmasında hangi rollere sahip olduğu ve turist rehberlerinin katkısının ne şekilde olduğu araştırılmıştır. Katılımcı görüşlerini ön plana çıarmak esas olduğu için doğrudan görüşlere yer verilmiştir. Gelecekte yapılacak yeni araştırmalarda, farklı bölgelerdeki turist rehberlerinin doğal, tarihi ve kültürel mirasın korunmasındaki ve aktarılmasındaki rollerinin incelenerek bir karşılaştırma yapılmasının literatüre katkı sağlaması beklenmektedir. Benzer şekilde turist rehberlerinin diğer rollerine ilişkin yapılacak çalışmaların konuya ilişkin bilgi birikiminin artırılmasına ve derinleştirilmesine fayda sağlayacağı düşünülmektedir.

\section{KAYNAKÇA}

Altınay, L., Paraskevas, A. and Jang, S. (2016). Planning Research in Hospitality and Tourism. London: Routledge.

Ap, J., and Wong, K. K. (2001). Case Study on Tour Guiding: Professionalism, Issues and Problems, Tourism Management, 22(5), 551-563.

Ariffin, A.A. and Maghzi, A., (2012). A Preliminary Study on Customer Expectations of Hotel Hospitality: Influences of Personal and Hotel Factors, International Journal of Hospitality Management, 31, 191-198.

Aslantürk Y. (2003). A grubu Seyahat Acentalarmnn Turist Rehberlerinden Beklentileri ve Beklentilerinin Karşılanma Derecesi. Yayınlanmamış Yüksek Lisans Tezi, Ankara: Gazi Üniversitesi Sosyal Bilimler Enstitüsü.

Avcıkurt, C. (2009). Turizm Sosyolojisi. Ankara: Detay Yayıncllı.

Birleşmiş Milletler Dünya Turizm Örgütü (United Nations World Tourism OrganisationUNWTO) (2019). Tourism and Culture Survey 2015 [Online] http://www2.unwto.org/webform/tourism-and-culture-survey-2015 [Erişim Tarihi: 11.02.2019].

Boniface, P. and Fowler, P. (2002). Heritage and Tourism in The Global Village. Routledge.

Bozkurt, A. (2016). Kültürel Turizm. İstanbul: Kriter Yayınevi.

Burns, P. M. and Holden, A. (1995). Tourism: A New Perspective. USA: FT Prenticehall.

Cohen, E. (1985). The Tourist Guide: The Origins, Structure and Dynamics of a Role, Annals of Tourism Research, 12(1), 5-29.

Cohen, E., M. Ifergan and E. Cohen (2002). A New Paradigm in Guiding: The Madrich as a Role Model, Annals of Tourism Research, 29(4): 919-32.

Çokal, Z. (2015). Bir Kültür Elçisi Olarak Profesyonel Turist Rehberinin Turistlere Aktarlan Kültürel Değerlere Katkısına Yönelik Turist Algılamaları: Kapadokya Örneği. Yayımlanmamış Yüksek lisans Tezi, Nevşehir Hacı Bektaş Veli Üniversitesi: Nevşehir.

Doğaner, S. (2013). Türkiye Kültür Turizmi, Doğu Kitabevi.

Dünya Turist Rehberleri Birliği Federasyonu (World Federation of Tourist Guide AssociationsWFTGA) (2019). What is a tour guide? [Online] http://www.wftga.org/tourist-guiding/whattourist-guide [Erişim Tarihi: 12.02.2019]. 
Emekli, G. (2006). Coğrafya, Kültür ve Turizm: Kültürel Turizm, Ege Coğrafya Dergisi, 15(1-2), 5159.

Fyall, A. and Garrod, B. (1998). Heritage Tourism: At What Price?, Managing Leisure, 3(4), 213-228.

Gunn, C.A. (1994). Tourism Planning: Basics, Concepts, Cases. Third Edition. Washington: Taylor and Francis.

Howard, J., Smith, B. and Thwaites, R. (2001). Investigating the Role of The Indigenous Tour Guide, Journal of Tourism Studies, 12(2), 32.

Hu, W. (2007). Tour Guides and Sustainable Development: The Case of Hainan, China. Yayımlanmamış Doktora Tezi, Waterloo, Ontario: Canada.

Hudman, L. E. and Hawkins, D. E. (1989). Tourism in Contemporary Society: An Introductory Text. USA: Prentice-Hall, Inc.

Huh, J. (2002). Tourist Satisfaction with Cultural/Heritage Site: The Virginia Triangle. Yayımlanmamış Yüksek Lisans Tezi. Virginia Polytechnic Institute and State University: USA.

Jansen-Verbeke, M. and McKercher, B. (2010). The Tourism Destiny of World Heritage Cultural Sites. In DG Pearce \& RW Butler (Eds.), Tourism Research: A 20-20 Vision, (pp. 190-202). Oxford: Goodfellow Publishers.

Jennings, G. and Weiler, B. (2006). Mediating Meaning: Perspectives on Brokering Quality Tourist Experiences, In Quality Tourism Experiences (pp. 75-96). Routledge.

Kaya, U. ve Özhan, Ç.K. (2012). Duygusal Emek ve Tükenmişlik İlişkisi: Turist Rehberleri Üzerine Bir Araştırma, Çalışma İlişkileri Dergisi, 3(2), 109-130.

Korkmaz, S., Temizkan, S.P. ve Temizkan, R. (2011). Hizmet İçi Eğitim Seminerlerinin Profesyonel Turist Rehberlerinin Turizm Pazarlamasındaki Rolüne Etkisi, İşletme Araştırmaları Dergisi, 3(2), 17-36.

Köroğlu, Ö. Köroğlu A. ve Alper B. (2012). Doğaya Dayalı Gerçekleştirilen Turizm Faaliyetleri İçerisinde Turist Rehberlerinin Rolleri Üzerine Bir İnceleme, KMÜ Sosyal ve Ekonomik Araşttrmalar Dergisi, 14 (22): 131-139.

Köroğlu, Ö. (2013). Turist Rehberlerinin İş Yaşamındaki Rolleri Üzerine Kavramsal Bir Değerlendirme, Pamukkale Üniversitesi Sosyal Bilimler Enstitüsü Dergisi, 16, 91-112.

Köroğlu, Ö. (2014). Meslek Seçimi ile Kişilik Özellikleri Arasındaki İlişkinin Belirlenmesi: Turizm Rehberliği Öğrencileri Üzerine Bir Araştırma, Süleyman Demirel Üniversitesi İktisadi ve İdari Bilimler Dergisi, 19(2), 137-157.

Látková, P., Jordan, E., Vogt, C., Everette, M., and Aquino, C. (2017). Tour Guides' Roles and Their Perceptions of Tourism Development in Cuba, Tourism Planning \& Development, 1- 17.

Leiper, N. (1990). Tourist Attraction Systems, Annals of Tourism Research, 17(3), 367-384.

Luoh, H. F. and Tsaur, S. H. (2014). The Effects of Age Stereotypes on Tour Leader Roles, Journal of Travel Research, 53(1), 111-123.

McKercher, B. (1999). A Chaos Approach to Tourism, Tourism Management, 20(4), 425-434.

McDonnell, I. (2001). The Role of the Tour Guide in Transferring Cultural Understanding, Working Paper No. 3; School of Leisure, Sport and Tourism, University of Technology, Sidney.

Nozawa, H. (1992). A Marketing Analysis of Japanese Outbound Travel, Tourism Management, 13(2), 226-234. 
Olcay, A., Bozgeyik, Y., Akköz, H. ve Sürme M. (2015). Profesyonel Turist Rehberlerinin Performanslarının Yerli Turistler Tarafından Değerlendirilmesi, İsletme Araştırmaları Dergisi, 7(2), 349-374.

Ormsby, A. and Mannle, K. (2006). Ecotourism Benefits and the Role of Local Tour Guides at Masoala National Park, Madagascar. Journal of Sustainable Tourism, 14(3), 271-287.

Prentice, R., (1993). Tourism and Heritage Attractions. London: Routledge.

Pond, K. (1993) The Professional Guide: Dynamics of Tour Guiding. New York: Van Nostrand Reinhold.

Rabotić, B. (2008). Tourist Guides as Cultural Heritage Interpreters: Belgrade Experience with Municipality-Sponsored Guided Walks for Local Residents. In International Tourism Conference: Cultural and Event Tourism Issues \& Debates (pp. 213-233).

Rabotić, B. (2010). Tourist Guides in Contemporary Tourism, International Conference on Tourism and Environment, Philip Noel-Baker University, Sarajevo, Bosnia \& Herzegovina, 4-5 March, pp. 353-364.

Rabotić, B. (2011). American Tourists' Perceptions of Tourist Guides in Belgrade, Journal of Economics, 2/2, 151-161.

Reisinger, Y. and Steiner, C. (2006). Reconceptualising Interpretation: The Role of Tour Guides in Authentic Tourism, Current Issues in Tourism, 9(6), 481-498.

Richards, G. (1996). Production and Consumption of European Cultural Tourism, Annals of Tourism Research, 23(2), 261-283

Sigala, M. and Leslie, D., (2005). International Cultural Tourism: Management, Implications and Cases. Oxford: Elsevier Butterworth-Heinemann

Smith, V. (1989). Hosts and Guests: The Anthropology of Tourism (2nd ed.). Philadelphia: University of Pennsylvania Press.

Smith, L. (2006). The Uses of Heritage. London: Routledge.

Şenol, F. ve Aliyev, İ. (2015). Türkiye'de Rus Turist Pazarına Hâkim Tur Acentalarında İstihdam Edilen Turist Rehberleri Üzerine Bir İnceleme, Kastamonu Üniversitesi İktisadi ve İdari Bilimler Fakültesi Dergisi, 8, 167-181.

Tosun, C. (2001). Challenges of Sustainable Tourism Development in The Developing World: The Case of Turkey. Tourism Management, 22(3), 289-303.

Tosun, C. ve Temizkan, R. (2004). Türkiye'nin Dış Tanıtım ve Ülke İmajında Turist Rehberlerinin Rolü, 1. Balıkesir Ulusal Turizm Kongresi Bildirileri, 15-16.

Timothy, D. J. and Boyd, S. W. (2006). Heritage Tourism in the 21st Century: Valued Traditions and New Perspectives, Journal of Heritage Tourism, 1(1), 1-16.

Timothy, D. J. and Nyaupane, G. P. (Eds.). (2009). Cultural Heritage and Tourism in The Developing World: A Regional Perspective. London: Routledge.

Toker, A. (2011). Kültür Turizminin Sürdürülebilirliğinde Profesyonel Turist Rehberlerinin Rolü: Ankara Örneği. Yayınlanmamış Yüksek Lisans Tezi, Anadolu Üniversitesi Sosyal Bilimler Enstitüsü, Eskişehir. 
UNESCO Türkiye Milli Komisyonu (2009). Türkiye'nin Dünya Miras Alanları. Koruma ve Yönetimde Güncel Durum. UNESCO Türkiye Milli Komisyonu Somut Kültürel Miras İhtisas Komitesi, Ankara, Türkiye.

Van der Merwe, C. D. (2016). Tourist Guides' Perceptions of Cultural Heritage Tourism in South Africa. Bulletin of Geography. Socio-economic Series, 34(34), 117-130.

Weiler, B. and Black, R. (2015). Tour Guiding Research: Insights, Issues and Implications. Bristol: Channel View Publications.

Yamada, N. (2011). Why Tour Guiding is Important for Ecotourism: Enhancing Guiding Quality with The Ecotourism Promotion Policy in Japan, Asia Pacific Journal of Tourism Research, 16(2), 139152.

Yetgin, D., and Benligiray, S. (2019). The Effect of Economic Anxiety and Occupational Burnout Levels of Tour Guides on Their Occupational Commitment, Asia Pacific Journal of Tourism Research, 24(4), 333-347.

Yıldırım, A. ve Şimşek, H. (2005). Sosyal Bilimlerde Nitel Araştırma Yöntemleri. Ankara: Seçkin Yayıncilik.

Yolal, M. (2016). Turizm Araştırmalarında Örnekleme: Bibliyometrik Bir Araştırma. Ankara: Detay Yayincilik.

Yu, X., Weiler, B. and Ham, S. (2002). Intercultural Communication and Mediation: A Framework for Analysing The Intercultural Competence of Chinese Tour Guides, Journal of Vacation Marketing, 8(1), 75-87. 